\title{
KESANTUNAN TINDAK TUTUR BAMAMAI DALAM BAHASA BANJAR: BERDASARKAN SKALA KESANTUNAN LEECH
}

\author{
Speech Act Politeness on Bamamai (nagging) in Banjar Language Based on \\ Politeness Scale by Leech
}

Jahdiah

Balai Bahasa Kalimantan Selatan

diah.banjar@yahoo.co.id

\begin{abstract}
Abstrak
Penelitian ini membahas mengenai tindak tutur bamamai (mengomel) dalam bahasa Banjar. Bamamai termasuk tindak tutur ekspresif. Bamamai biasanya melibatkan emosi penutur kepada mitra tutur ketika tuturan mitra tutur tidak sesuai dengan yang diinginkan oleh penutur. Penelitian ini bertujuan mendeskripsikan tindak tutur bamamai berdasarkan skala kesantunan Leech. Metode yang digunakan dalam penelitian ini adalah metode deskripsif kualitatif. Data yang dikumpulkan berbentuk deskriptif percakapan penutur berbahasa Banjar dalam ragam lisan. Teori yang digunakan dalam penelitian ini skala kesantunan yang dikemukakan oleh Leech, yaitu (1) skala kerugian dan keuntungan, (2) skala pilihan, (3) skala ketidaklangsungan, (4) skala keotoritasan, dan (5) skala jarak. Hasil penelitian menunjukkan bahwa dalam tindak tutur bamamai terdapat tuturan yang santun karena sesuai dengan skala kesantunan yang dikemukakan oleh Leech, yaitu skala ketidaklangsungan, keotoritasan, dan pilihan. Sebaliknya, dalam tindak tutur bamamai terdapat tuturan yang tidak santun karena tidak sesuai dengan skala ketidaklangsungan dan skala jarak sosial.
\end{abstract}

Kata-kata Kunci: bamamai, bahasa Banjar, dan skala kesantunan.

\begin{abstract}
This study discusses speech act of bamamai (nagging) in Banjar language. Bamamai is an expressive speech act. Bamamai usually involves the speaker's emotion toward the speech partner when the speech is not in accordance with what the speaker wants. This research aims to describe bamamai speech acts based on Leech's politeness scale. The method used in this research is descriptive qualitative. The data collected are descriptive, taken from the speakers' conversations in Banjar language's oral variety. The theory used in this research is the politeness scale by Leech, namely (1) cost and benefit scale, (2) optionality scale, (3) indirectness scale, (4) authority scale and (5) distance scale. The research shows that there are polite speeches in the bamamai (nagging) speech act because they are in accordance with Leech's politeness scale, namely the indirectness, authority and optionality scale. On the other hand, there are impolite speeches in bamamai (nagging) speech act because they are not in accordance with the indirectness scale and social distance scale.
\end{abstract}

Keywords: bamamai (nagging), Banjar language, politeness scale 
How to Cite: Jahdiah. (2018). Kesantunan Tindak Tutur Bamamai dalam Bahasa Banjar: Berdasarkan Skala Kesantunan Leech, Ranah: Jurnal Kajian Bahasa, 7 (2), 164-179. doi: https://doi.org/10.26499/rnh.v7i2.530

\section{PENDAHULUAN}

Bahasa Banjar sebagai bahasa daerah mempunyai landasan konstitusional yang kukuh. Oleh karena itu, pembinaan, pengembangan, dan pelestarian bahasa Banjar tersebut dipelihara oleh negara, yang termuat dalam UUD 1945, BAB XV, Pasal 36. Dengan demikian, bahasa Banjar mempunyai hak yang sama dengan bahasa daerah yang lain di Indonesia.

Bahasa Banjar dipakai oleh masyarakat yang mendiami daerah Kalimantan Selatan sebagai bahasa yang komunikatif. Selain itu, bahasa Banjar juga merupakan kebanggaan penutur asli, lambang yang berciri khas daerah, serta sebagai alat pemersatu antarpenuturnya.

Dalam pergaulan sehari-hari masyarakat Banjar sering bercampur dengan sukusuku lain yang ada di sekitarnya, yaitu suku Dayak, suku Jawa, dan suku Madura. Sebagai akibatnya pergaulan suku Banjar dengan suku-suku lain itu, bahasa Banjar mendapat pengaruh dari bermacam-macam bahasa daerah di sekitarnya (Jahdiah, 2010).

Bahasa Banjar terbagi atas dua dialek besar, yaitu dialek bahasa Banjar Kuala (BBK) dan dialek bahasa Banjar Hulu (BBH). Dialek BBK umumnya dipakai oleh penduduk asli sekitar kota Banjarmasin, Martapura, Pelaihari, dan Kota baru, sedangkan dialek BBH umumnya dipakai oleh penduduk di daerah Hulu Sungai pada umumnya, yaitu daerah-daerah seperti Kabupaten Tapin, Kabupaten Hulu Sungai Selatan, Kabupaten Sungai Tengah, Kabupaten Hulu Sungai Utara, dan Kabupaten Tabalong, dan Kabupaten Balangan.

Dalam Kamus Banjar-Indonesia, Hapip (2008) mengemukakan bahwa berdasarkan pengamatan yang ada, perbedaan antara dialek BBK dan BBH dapat dilihat dari dua hal, yaitu (1) adanya perbedaan kosakata tertentu dan (2) perbedaan bunyi ucapan terhadap fonem tertentu.

Untuk menjaga keaslian bahasa Banjar, perlu dilakukan penelitian bahasa Banjar. Bahasa Banjar dapat dikaji dari berbagai tataran. Dari tataran fonologi, morfologi, sintaksis, semantik, dan wacana. Dari segi pragmatik juga banyak segi yang bisa dijadikan objek kajian. Kesantunan berbahasa merupakan bagian dari kajian pragmatik. 
Bahasa Banjar seperti juga bahasa lain juga mempunyai tindak tutur bamamai. Menurut Kamus Bahasa Banjar Dialek Hulu-Indonesia yang disusun Musdalifah (2008), bamamai bermakna mengomel atau marah-marah. Kebiasaan bamamai ini biasa lebih sering dilakukan oleh kaum perempuan sehingga di Banjar ada istilah latupan cabi. Istilah ini biasa digunakan untuk perempuan yang suka mengomel. Tindak tutur bamamai perlu dilakukan penelitian mengenai kesantunan berbahasa. Karena dalam tindak tutur bamamai biasa dilakukan oleh penutur jika keinginan penutur tidak dikabulkan atau berbeda dengan keinginan penutur. Dalam tindak tutur bamamai (mengomel) ada keterlibatan emosi antara penutur dan mitra tutur sehingga perlu adanya kesantunan.

Penggunaan kesantunan berbahasa tidak saja ditentukan oleh pilihan tuturannya, melainkan juga oleh aspek-aspek lain yang turut menentukan tingkat kesantunan, misalnya usia, jarak sosial antara penutur dan petutur, situasi, waktu, tempat, dan tujuan tuturan. Dengan demikian, dalam penggunaan bahasa perlu diperhatikan konteks pemakaian bahasa. Hal ini sejalan dengan pendapat Holmes (2001) yang menyatakan bahwa bersikap santun secara kebahasaan berkaitan dengan pemilihan bentuk-bentuk bahasa yang mampu mengungkapkan besarnya jarak sosial yang sesuai atau mengenali perbedaan-perbedaan kekuasaan atau status yang relevan.

Berbahasa secara baik, benar, dan santun dapat menjadi kebiasaan dan dapat membentuk perilaku seseorang menjadi lebih baik. Dari kenyataanya, selain bentuk isi, kesantunan dapat pula dimanifestasikan dalam bentuk 'cara' pengelolaan dan penstrukturan percakapan oleh peserta tutur. Misalnya, dalam tuturan dengan orang yang lebih tua, perilaku percakapan seperti berbicara pada saat yang tidak tepat menyela atau diam dapat membawa kesan dan implikasi yang dianggap tidak sopan. Akibatnya, kadang-kadang dipandang perlu untuk mengacu kepada tindak tutur yang dilakukan penutur atau yang dilakukan partisipan lain.

Menurut Yayuk (2016), santun berbahasa ini tidak begitu saja diperolehnya kala dia dewasa melalui dunia pendidikan formal. Dunia pendidikan di lingkungan keluarga yang membesarkannya sejak kecil adalah salah satu ranah penentu bagi pertumbuhan dan perkembangan santun berbahasa yang dimilikinya. Bagi masyarakat daerah, pendidikan santun berbahasa di dalam keluarga ini dilakukan antara lain melalui tindak tutur keseharian yang diujarkan oleh orang tua kepada generasi berikutnya.

Kesantunan merupakan salah satu prinsip yang sangat penting dalam penggunaan bahasa. Dalam berbahasa perlu dipertimbangkan perasaan orang lain. Dengan 
mempertimbangkan perasaan orang lain itulah, komunikasi perlu memperhatikan kesantunan berbahasa. Penggunaan kesantunan berbahasa memungkinkan transaksi sosial berlangsung tanpa mempermalukan penutur dan petutur.

Menurut Pranowo (2012), pilihan kata merupakan salah satu penentu kesantunan, baik dalam bahasa lisan maupun tulisan. Ketika seorang penutur sedang bertutur, katakata yang digunakan dipilih sesuai dengan topik yang dibicarakan, konteks pembicaraan, suasana mitra tutur, dan pesan yang disampaikan.

Untuk dapat berbahasa dengan santun dan dengan perilaku yang sesuai dengan etika berbahasa, tentu harus dipenuhi dulu persyaratan bahwa penutur telah menguasai bahasa dengan baik Chaer (2010).

Penelitian yang terkait dengan kesantunan yang pernah dilakukan, antara lain, Zaini (2009) dengan judul penelitian "Kesantunan Direktif Bahasa Banjar”. Hasil penelitian ini menunjukkan bahwa maksim PK terealisasi dalam direktif bahasa Banjar, meliputi (1) maksim kearifan, (2) kedermawanan, (3) pujian, (4) kerendahan hati, (5) kesepakatan, dan (6) simpati. Dalam tuturan ditemukan beberapa bentuk kesantunan direktif. Bentuk kesantunan direktif bahasa Banjar meliputi bentuk langsung imperatif yang mencakup (1) aktif transitif dan taktransitif, (2) pasif, dan (3) kesantunan. Selain menggunakan bentuk imperatif, penutur dapat menggunakan bentuk tak langsung deklaratif yang bermakna suruhan, ajakan, permohonan, persilaan, dan larangan.

Di samping itu, penutur dapat pula menggunakan bentuk tuturan tak langsung lainnya dalam direktif, yaitu interogatif suruhan, ajakan, permintaan, persilaan, dan larangan. Dalam direktif bahasa Banjar ditemukan tuturan yang tak langsung lebih tidak santun daripada tuturan langsungnya. Tuturan itu dalam konteks memperingatkan dengan keras. Dalam mewujudkan kesantunan direktif ditemukan sepuluh strategi, yaitu strategi imperatif, pernyataan permintaan, permintaan berpagar, pernyataan keharusan, pernyataan keinginan, rumusan saran, rumusan pertanyaan, isyarat kuat, isyarat halus, dan ironi. Kesantunan direktif bahasa Banjar mempunyai sejumlah fungsi, yakni untuk tindakan menyelamatkan muka, tindakan menghindari konflik, tindakan mencapai efektivitas, dan tindakan memberikan penghormatan. Kesantunan direktif tidak hanya banyak ditemukan dari tuturan orang dewasa, tetapi banyak pula ditemukan dalam tuturan anak-anak yang berfungsi sebagai tindakan mencapai efektivitas tujuan. Strategi kesantunan direktif yang banyak ditemukan dalam penelitian ini adalah strategi isyarat kuat, isyarat halus, dan ironi. 
Penelitian berikutnya dilakukan oleh Yayuk (2015) dengan judul tulisan "Etika Berbahasa dalam Masyarakat Banjar”. Penelitian ini membahas mengenai jenis tindak tutur bahasa Banjar dengan teori kesantunan Yueguo Gu yang menekankan pada empat prinsip sopan santun, yaitu (1) maksim denigrasi diri (self-denigration), (2) maksim sapaan (address), (3) maksim ketimbangrasaan (tact), dan (4) maksim keseimbangan (balance). Jahdiah (2016) dengan judul "Strategi Permintaan dalam Bahasa Banjar: Tinjauan Kesantunan Berbahasa”. Penelitian ini membahas mengenai strategi permintaan dalam bahasa Banjar dikaitkan dengan skala kesantunan yang dikemukakan oleh Robin Lakoff (dalam Rahardi, 2005: 70). Hasil penelitian menjelaskan bahwa ada delapan strategi tuturan permintaan yang terdapat dalam bahasa Banjar, yaitu (1) meminta, (2) bertanya, (3) menyapa, (4) memberi informasi, (5) saran, (6) menawarkan, (7) mengutip, dan (8) menyindir. Masing-masing strategi tersebut menerapkan skala kesantunan yang dikemukan oleh Robin Lakoff. Penelitian lain yang juga membahas tentang kesantunan dalam bahasa Banjar, yaitu Yayuk (2015) dengan judul penelitian "Wujud Kesantunan Asertif dan Imperatif dalam bahasa Banjar”. Penelitian ini membahas wujud kesantunan tindak tutur asertif dalam bahasa Banjar berupa basa-basi, sapaan. Sementara itu, wujud tindak tutur imperatif berupa wujud basa-basi, wujud sapaan, dan pamali. Kedua jenis tindak tutur tersebut masing-masing menerapkan kesantunan berbahasa berdasarkan prinsip kesantunan yang ada di masyarakat. Penelitian mengenai tindak tutur bamamai belum pernah dilakukan, baik dari segi teori maupun pendekatan, sehingga peneliti tertarik untuk meneliti mengenai kesantunan tindak tutur bamamai.

Berdasarkan latar belakang di atas, masalah yang dibahas dalam penelitian ini ialah bagaimana penerapan skala kesantunan Leech dalam Rahardi (2015) dalam tindak tutur bamamai dalam bahasa Banjar dan bagaimana pelanggaran skala kesantunan Leech dalam Rahardi (2015) dalam tindak tutur bamamai (mengomel) dalam bahasa Banjar. Tujuan penelitian ini mendeskripsikan penerapan dan pelanggaran skala kesantunan dalam Rahardi (2015) dalam tindak tutur bamamai. Manfaat penelitian ini diharapkan dapat memberikan sumbangan untuk pengembangan teori linguistik pada umumnya dan teori dan konsep pragmatik bahasa Indonesia khususnya.

\section{LANDASAN TEORI}

Penelitian ini menggunakan pendekatan pragmatik sebagai dasar untuk menganalisis data. Kesantunan berbahasa termasuk dalam kajian pragmatik. Pragmatik 
adalah studi tentang penggunaan bahasa dalam komunikasi, khususnya kajian tentang hubungan antarkalimat dengan konteks dan situasi yang diacu oleh kalimat tersebut Jumanto (2017). Sementara itu, Yule (2006) “memandang pragmatik meliputi empat ruang lingkup. Pertama, pragmatik merupakan studi tentang maksud penutur. Kedua, pragmatik adalah studi tentang makna kontekstual. Ketiga, pragmatik adalah studi tentang bagaimana agar lebih banyak yang “disampaikan” daripada yang “dituturkan”. Keempat, pragmatik adalah studi tentang pengungkapan dari jarak hubungan”.

Pragmatik merupakan disiplin ilmu baru yang bersinggungan dengan ilmu-ilmu lain. Ilmu-ilmu tersebut adalah linguistik, sosiolinguistik, dan semantik. Persinggungan itu tampak pada titik pusat kajian, yaitu kalimat Putrayasa (2015). Sementara itu, menurut Yusri (2016) pragmatik merupakan salah satu cabang ilmu bahasa yang boleh dikatakan berbeda dengan ilmu bahasa strukturalis. Pragmatik merupakan ilmu bahasa yang mempelajari relasi antara tanda, makna dan konteks.

Dalam pragmatik, ada dua hal penting yang perlu dicermati, yakni penggunaan bahasa dan konteks. Penggunaan bahasa di sini menyangkut fungsi bahasa (language function), sedangkan konteks terkait erat dengan budaya di dalam masyarakat, yang menunjukkan ketidaksamaan masyarakat antara yang satu dan masyarakat yang lainnya. (Sulistyo, 2013:4)

Penggunaan bahasa untuk komunikasi di suatu masyarakat, utamanya dalam menerapkan prinsip kesantunan, berlaku secara berbeda-beda. Perbedaan tersebut berlaku dalam kebudayaan dan masyarakat pengguna bahasa dalam situasi-situasi sosial yang berbeda, dalam kelas-kelas sosial yang berbeda antara masyarakat yang satu dan masyarakat yang lainnya (Sulistyo, 2013: 6).

Fenomena-fenomena kebahasaan yang dipelajari di dalam pragmatik juga berkembang terus-menerus dari waktu ke waktu. Fenomena-femomena pragmatik itu di antaranya adalah implikatur, deiksis, praanggapan (presupposition) ikutan (entailment), kesantunan berbahasa, ketidaksantunan berbahasa, dan basa-basi dalam berbahasa (Rahardi, 2016: 21).

Kajian tentang kesantunan ada beberapa pendapat, yakni kesantunan Leech dalam Rahardi (2015), pada bagian ini hanya skala kesantunan Leech dalam Rahardi (2015) yang dibahas karena teori tersebut yang dijadikan acuan untuk analisis data.

Di dalam model kesantunan Leech dalam Rahardi (2015) setiap maksim interpersonal dapat dimanfaatkan untuk menentukan peringkat kesantunan sebuah 
tuturan. Berikut skala kesantunan yang disampaikan Leech itu selengkapnya dalam Rahardi (2005).

1) Cost-benefit scale atau skala kerugian dan keuntungan, menunjuk kepada besar kecilnya kerugian dan keuntungan yang diakibatkan oleh sebuah tindak tutur pada sebuah pertuturan. Semakin tuturan tersebut merugikan diri penutur maka dianggap santunlah tuturan itu. Sebaliknya, semakin tuturan itu menguntungkan diri penutur, maka dianggap tidak santunlah tuturan itu. Jika dilihat dari kacamata si mitra tutur dapat dikatakan bahwa semakin menguntungkan diri mitra tutur, akan semakin dipandang santunlah tuturan itu. Demikian sebaliknya, semakin tuturan itu merugikan diri si mitra tutur akan dianggap semakin tidak santunlah tuturan itu.

2) Optionality scale atau skala pilihan, menunjuk kepada banyak atau sedikitnya pilihan (options) yang disampaikan si penutur kepada si mitra tutur di dalam kegiatan bertutur. Semakin pertuturan itu memungkinkan penutur atau mitra tutur menentukan pilihan yang banyak dan leluasa akan dianggap santunlah tuturan itu, Sebaliknya, jika pertuturan itu sama sekali tidak memberikan kemungkinan memilih bagi si penutur dan si mitra tutur, tuturan tersebut akan dianggap tidak santun.

3) Indirectness scale atau skala ketidaklangsungan menunjuk kepada peringkat langsung atau tidak langsungnya maksud sebuah tuturan. Semakin tuturan itu bersifat langsung akan dianggap semakin tidak santunlah tuturan itu. Sebaliknya, semakin tidak langsung maksud sebuah tuturan akan dianggap santunlah tuturan itu.

4) Authority scale atau skala keotoritasan menunjuk kepada hubungan status sosial antara penutur dan mitra tutur yang terlibat dalam petuturan. Semakin jauh jarak peringkat sosial (rank rating) antara penutur dan mitra tutur, tuturan yang digunakan akan cenderung menjadi santun. Sebaliknya, semakin dekat jarak peringkat status sosial di antara keduanya akan cenderung berkuranglah peringkat kesantunan tuturan yang digunakan dalam bertutur itu.

5) Social distance scale atau skala jarak sosial menunjuk kepada peringkat hubungan sosial antara penutur dan mitra tutur yang terlibat dalam sebuah pertuturan. Ada kecenderungan bahwa semakin dekat jarak peringkat sosial di antara keduanya, akan menjadi semakin kurang santunlah tuturan itu. Demikian sebaliknya, semakin jauh jarak peringkat sosial antara penutur dengan mitra tutur akan santunlah tuturan yang digunakan itu. Dengan perkataan lain, tingkat keakraban hubungan antara penutur dan 
mitra tutur sangat menentukan peringkat kesantunan tuturan yang digunakan dalam bertutur.

\section{METODE PENELITIAN}

Metode yang digunakan dalam kajian ini adalah metode deskriptif. Untuk mencapai deskripsi yang kualitatif, penelitian ini menerapkan tiga tahapan, yaitu 1) tahap penyediaan data, 2) tahap analisis data, dan 3) tahap penyajian hasil (Sudaryanto, 2015). Dalam rangka penyediaan data digunakan metode simak yang diikuti oleh teknik catat. Hasil penyimakan dan pencatatan digunakan sebagai data kemudian diklasifikasikan selanjutnya dianalisis. Teknik analisis data digunakan dalam penelitian ini ialah model analisis interaktif yang dikemukakan oleh Miles dan Huberman dalam Wahyu (2006). Model analisis interaktif lebih tepat digunakan sebab relevan dengan penelitian ini. Relevansi itu dapat dilihat pada karakteristik analisis model interaktif, yakni (1) dapat dilakukan dengan empat langkah: (a) selama pengumpulan data, (b) pereduksian data, (c) penyajian data, dan (d) penyimpulan data; dan (2) keempat langkah itu terjadi bersamaan, berhubungan, berlanjut, dan berulang.

\section{HASIL DAN PEMBAHASAN}

1. Penerapan Skala Kesantunan Leech dalam Tindak Tutur Bamamai (Mengomel) dalam Bahasa Banjar

Di dalam model kesantunan Leech dalam Rahardi (2015), setiap maksim interpersonal dapat dimanfaatkan untuk menentukan peringkat kesantunan sebuah tuturan. Tuturan dikatakan santun apabila sesuai dengan skala yang ditentukan. Berikut penerapan analisis kesantunan tindak tutur bamamai (mengomel) dalam bahasa Banjar.

\section{Data 1}

Umaylah ikam nawar banar jualan mun harga kada sampai poko lagi kaya apa handak manjualinya.

'Aduh kamu sekali menawar sekali kalau harga belum sampai modal, bagaimana mau menjual.

Konteks tuturan:

Seorang pedagang dengan pembeli ketika terjadi transaksi jual beli.

Tuturan Umaylah ikam nawar banar jualan mun harga kada sampai poko lagi kaya apa handak manjualinya 'Aduh kamu sekali menawar sekali kalau harga belum sampai modal, bagaimana mau menjual' dituturkan oleh seorang pedagang kepada pembeli yang cerewet menawar dagangan dengan mitra tutur. Tuturan yang dituturkan 
penutur termasuk tindak tutur bamamai 'mengomel' berdasarkan skala kesantunan Leech dalam Rahardi (2015), yaitu skala kerugian dan keuntungan (cost-benefit scale) tuturan tersebut termasuk tuturan yang santun. Skala ini menunjukkan besar kecilnya kerugian dan keuntungan yang diakibatkan sebuah tuturan. Tuturan tersebut semakin merugikan diri penutur sehingga akan semakin dianggap santun. Berikut juga analisis kesantunan berdasarkan skala kesantunan yang dikemukakan oleh Leech dalam Rahardi (2015).

\section{Data 2}

Matan kamana ikam lawasnya unda mahadangi saisukan.

'Dari mana kamu lama sekali saya menunggu dari pagi'.

\section{Konteks tuturan:}

Penutur dan mitra tutur berjanji akan pergi bersama.

'Dari mana kamu lama sekali saya menunggu dari pagi' dituturkan oleh penutur kepada mitra tutur ketika mereka berdua berjanji akan pergi ke rumah kawan mereka yang sudah lama tidak bertemu. Tuturan yang dituturkan oleh penutur termasuk tuturan bamamai (mengomel). Berdasarkan skala kesantunan yang dikemukakan oleh Leech dalam Rahardi (2015), tuturan tersebut tergolong tuturan yang santun berdasarkan skala keotoritasan (authority scale) atau menunjukkan kepada hubungan status sosial antara penutur dan mitra tutur yang terlibat dalam bertuturan. Berdasarkan skala tersebut, tuturan pada Data 2 termasuk tuturan yang santun. Berikut juga analisis tuturan bamamai (mengomel) berdasarkan skala kesantunan yang dikemukan oleh Leech dalam Rahardi (2015).

\section{Data 3}

Bubuhan ikam ne lah muyak banar sudah ditagur kada maasi jua.

'Kalian ini ya, bosan saya menasihati tidak menurut juga'

\section{Konteks tuturan:}

Seorang ibu mengingatkan anaknya.

Tuturan Bubuhan ikam ne lah muyak banar sudah ditagur kada maasi jua. 'Kalian ini ya, bosan saya menasihati tidak menurut juga' dituturkan oleh seorang ibu kepada anak-anaknya yang tidak mau berhenti bermain-main. Tuturan tersebut termasuk bamamai. Penutur bamamai ketika melihat anak-anaknya masih sibuk bermain padahal waktu sudah hampir Magrib. Berdasarkan skala kesantunan yang dikemukakan oleh Leech dalam Rahardi (2015), tuturan itu termasuk yang santun, yaitu skala keotoritasan (authority scale). Skala itu menunjukkan hubungan status sosial penutur dan mitra tutur yang terlibat dalam petuturan. Tuturan tersebut dituturkan oleh seorang ibu kepada anaknya. Skala keotoritasan tuturan tersebut termasuk tuturan yang santun karena seorang 
ibu wajar saja mengingatkan anaknya. Berikut juga analisis kesantunan bamamai (mengomel) dalam bahasa Banjar.

\section{Data 4}

Ikam ne kaya apa aku ditinggal, sudah mahadangi matan baisukan tadi.

"Kamu ini bagaimana saya ditinggalkan, saya menunggu dari pagi tadi'.

Konteks tuturan:

Seorang teman marah ketika temannya meninggalkan.

Tuturan Ikam ne kaya apa aku ditinggalan, sudah mahadangi matan baisukan tadi 'Kamu ini bagaimana saya ditinggalkan, saya menunggu kamu dari pagi tadi' dituturkan oleh penutur kepada mitra tutur karena ditinggal sendiri di tempat acara pengantinan. Tuturan itu termasuk tuturan yang santun berdasarkan skala kesantunan yang dikemukakan oleh Leech dalam Rahardi (2015), yaitu skala jarak sosial skala itu menunjukkan hubungan status sosial antara penutur dan mitra tutur. Jarak sosial yang dimaksud pada tuturan tersebut ditentukan oleh umur. Data 4 jarak umur antara penutur dan mitra tutur dekat.

\section{Data 5}

Aku kada rela dunia akhirat wan nyawa mun manguya kaburukan unda lawan kawan nang lain. 'Saya tidak rela dunia akhirat kalau kamu mengunjing kejelekan saya dengan teman yang lain. Konteks tuturan: Penutur bertemu dengan mitra tutur ketika acara perkawinan teman mereka.

Tuturan Aku kada rela dunia akhirat wan nyawa mun manguya kaburukan unda lawan kawan nang lain 'Saya tidak rela dunia akhirat kalau kamu menggunjing kejelekan saya dengan teman yang lain’ dituturkan penutur kepada mitra tutur karena mitra tutur menjelekkan penutur di depan teman yang lain. Tuturan itu termasuk tuturan yang santun berdasarkan skala kerugian dan keuntungan (cost-benefit scale). Skala ini berarti bahwa semakin sebuah tuturan merugikan penutur, tuturan tersebut semakin santun. Tuturan itu jelas sangat merugikan diri penutur sehingga jika dihubungkan dengan skala kerugian dan keuntungan termasuk tuturan yang santun.

\section{Pelanggaran Skala Kesantunan Leech dalam Tindak Tutur Bamamai (Mengomel) dalam Bahasa Banjar}

Pelanggaran terhadap skala kesantunan Leech dalam Rahardi (2015), akan menyebabkan sebuah tuturan tidak santun. Berikut analisis tindak tutur bamamai (mengomel) yang tidak santun.

\section{Data 6}

Mun batatukar dipikaran tapakai kada kah mun kada parlu ditukari mambuang-buang duit haja, baik disimpani duit. 
'Kalau belanja, dipikirkan digunakan; kalau tidak perlu, jangan dibeli membuang-buang uang saja, lebih baik disimpan uangnya`.

\section{Konteks tuturan:}

Seorang ibu menasihati anak yang suka berbelanja.

Tuturan Mun batatukar dipikaran tapakai kada kah mun kada parlu ditukari mambuang-buang duit haja, baik disimpani duit 'Kalau belanja, dipikirkan digunakan; kalau tidak perlu, jangan dibeli membuang-buang uang saja; lebih baik disimpan uangnya' termasuk tuturan bamamai (mengomel). Penutur mengomel panjang lebar kepada mitra tutur ketika melihat anaknya selalu belanja barang-barang yang tidak diperlukan hampir setiap dia mempunyai uang. Berdasarkan skala kesantunan yang dikemukakan oleh Leech dalam Rahardi (2015), tuturan itu termasuk jenis skala ketidaklangsungan (indirecness scale). Skala ketidaklangsungan menunjukkan kepada peringkat langsung atau tidak langsungnya maksud sebuah tuturan. Tuturan yang semakin bersifat langsung akan dianggap tidak santun. Pada tuturan tersebut penutur secara langsung bamamai (mengomel) kepada mitra tutur. Dengan demikian, tuturan tersebut termasuk tuturan yang kurang santun.

\section{Data 7}

Muyak sudah unda manjalas kada sing pahaman jua kayapan nyawa ne.

'Bosan sudah saya menjelaskan tidak mengerti jua, bagaimana kamu ini'.

Konteks tuturan:

Penutur menjelaskan kepada mitra tutur tentang sebab dia terlambat datang.

Tuturan Muyak sudah unda manjalas kada sing pahaman jua kayapan nyawa ne 'Bosan sudah saya menjelaskan tidak mengerti jua, bagaimana kamu ini' dituturkan oleh penutur kepada mitra tutur ketika penutur terlambat datang pada acara selamatan, tetapi mitra tutur tetap saja bertanya terus kepada penutur sehingga penutur marah dan sambil bamamai penutur menjelaskannya. Berdasarkan skala kesantunan yang dikemukan oleh Leech dalam Rahardi (2015), tuturan tersebut termasuk tuturan yang tidak santun. Berdasarkan skala ketidaklangsungan (indirectness scale), skala ini menunjukkan peringkat langsung atau tidak langsungnya sebuah tuturan. Akan tetapi, jika penutur lebih tua atau yang mempunyai otoritas, tuturan tersebut bisa berubah menjadi tuturan yang santun jika dilihat dari skala yang berbeda, yaitu skala keotoritasan. Tuturan yang semakin bersifat langsung akan dianggap semakin tidak santun tuturan itu. Tuturan itu termasuk tuturan yang secara langsung ditujukan kepada mitra tutur. 


\section{Data 8}

Mun kada kada katuju jangan dipaksa umpat mun muha marangut tarus.

'Kalau tidak senang, jangan dipaksa; kamu ikut, wajah cemberut saja'.

Konteks tuturan:

Penutur memaksa mitra tutur untuk ikut ke rumahnya.

Tuturan Mun kada kada katuju jangan dipaksa umpat mun muha marangut tarus 'Kalau tidak senang, jangan dipaksa; kamu ikut, muka masam’ dituturkan oleh seorang teman kepada temannya ketika temannya menunjukkan muka tidak senang. Tuturan tersebut termasuk tuturan yang santun berdasarkan skala pilihan dalam kontek kalimat. Berdasarkan skala ini, banyak sedikitnya pilihan yang disampaikan penutur kepada mitra tutur di dalam pertuturan, semakin sebuah tuturan memungkinkan mitra tutur. Menentukan pilihan yang lebih banyak akan leluasa dan semakin santun sebuah tuturan. Tuturan itu termasuk tuturan yang memungkinkan mitra tutur mempunyai pilihan untuk menentukan sikap.

\section{Data 9}

Mun kada handak manukari jangan diwada jajualan ampun unda. 'Kalau tidak mau membeli, jangan dihina jualan saya.'

\section{Konteks Tuturan:}

Percakapan terjadi di pasar ketika pembeli tidak jadi membeli dengan mengatakan jeruk masam.

Tuturan Mun kada handak manukari jangan diwada jajualan ampun unda. Kalau tidak mau membeli, jangan dihina jualan saya' dituturkan oleh seorang penjual kepada pembeli ketika pembeli tidak jadi membeli jeruk yang ditawarkan penjual dengan alasan jeruk terlalu masam. Tuturan itu termasuk tindak tutur bamamai (mengomel). Penutur bamamai kepada mitra tutur yang telah mengatakan bahwa jeruk masam. Berdasarkan skala kesantunan yang dikemukan oleh Leech dalam Rahardi (2015), yaitu skala ketidaklangsungan (indirectness scale), tuturan itu termasuk tuturan yang tidak santun karena berdasarkan skala ketidaklangsungan bahwa semakin tuturan bersifat langsung akan dianggap tidak santun berdasar skala yang dikemukan oleh Leech dalam Rahardi (2015). Tuturan tersebut termasuk tuturan yang tidak santun karena penutur langsung bamamai (mengomel) ketika pembeli mengatakan bahwa jeruk masam tidak jadi membelinya.

\section{Data 10}

Ayunah lakasi makannah muyak banar ikam ne handak bapaminan haja gawiannya. 'Ayo, cepat makan ya, bosan sekali kamu ini, mau main-main saja kerjaannya.'

\section{Konteks tuturan:}

Seorang ibu menawari anaknya makan ketika anak asyik main. 
Tuturan Ayunah lakasi makannah muyak banar ikam ne handak bapaminan haja gawiannya 'Ayo, cepat makan ya, bosan sekali kamu ini, mau main-main saja kerjaannya' dituturkan oleh seorang ibu kepada anaknya ketika menyuruh anaknya makan karena anak tidak segera makan, maka penutur bamamai (mengomel) kepada anaknya. Berdasarkan skala kesantunan yang dikemukakan oleh Leech dalam Rahardi (2015), yaitu skala jarak sosial (social distance scale), tuturan itu termasuk tuturan yang tidak santun. Berdasarkan skala jarak sosial, ada kecenderungan bahwa semakin dekat jarak peringkat sosial di antara penutur dan mitra tutur semakin kurang santun.

\section{Data 11}

Anak nyawa jua nang macal jadi kada dikawani kakanakan nang lain, ikam jangan manyalahan anak urang saja, anak sorang nang diajari dulu.

"Anak kamu juga yang nakal sehingga tidak ditemani anak-anak yang lain, kamu jangan menyalahkan anak orang saja, anak sendiri dulu yang diajari’.

\section{Konteks tuturan:}

Penutur marah ketika mitra tutur memarahi anaknya.

Tuturan Anak nyawa jua nang macal jadi kada dikawani kakanakan nang lain, ikam jangan manyalahan anak urang saja, anak sorang nang diajari dulu 'Anak kamu jua yang nakal sehingga tidak ditemani anak-akan yang lain, kamu jangan menyalahkan anak orang saja, anak sendiri dulu yang diajari' termasuk tuturan bamamai (mengomel). Berdasarkan skala kesantunan yang dikemukakan oleh Leech dalam Rahardi (2015), yaitu skala jarak sosial (social distance scale), tuturan itu termasuk tuturan yang tidak santun. Karena berdasarkan skala jarak sosial, ada kecenderungan sekat jarak sosial di antara keduanya sehingga akan menjadi semakin kurang santun tuturan tersebut. Sebaliknya, semakin jauh jarak peringkat sosial antara penutur dan mitra tutur, tuturan akan semakin santun. Tuturan itu dituturkan oleh dua sahabat sehingga jarak sosial keduanya dekat sehingga tuturan yang dituturkan kurang santun.

\section{Data 12}

Umaylah muar banar unda kaya ini kanapa ikam kada dibawakan padahal ikam bapadah handak mambawakan.

'Aduh benci saya kalau begini, mengapa kamu tidak membawakan padahal kamu sudah mau membawakan.'

\section{Konteks tuturan:}

Penutur marah kepada mitra tutur karena mitra tutur lupa membawakan kue pesanan penutur.

Tuturan Umaylah muar banar unda kaya ini kanapa ikam kada dibawakan padahal ikam bapadah handak mambawakan 'Aduh benci saya kalau begini, mengapa 
kamu tidak membawakan padahal kamu sudah mau' dituturkan oleh penutur kepada mitra tutur. Penutur bamamai (mengomel) kepada mitra tutur karena mitra tutur lupa membawakan kue pesanan penutur. Berdasarkan skala yang dikemukakan oleh Leech dalam Rahardi (2015), yaitu skala ketidaklangsungan, tuturan itu temasuk tuturan yang tidak santun. Berdasarkan skala itu, tuturan yang semakin bersifat langsung akan dianggap semakin tidak santun. Pada tuturan tersebut penutur langsung bamamai (mengomel) karena mitra tutur lupa membawakan apa yang telah dipesan oleh penutur.

\section{Data 13}

Ikam tu ding mun bajalan jangan barianan, ikam babinian di rumah haja mun sudah datang matan sakulahan.

'Kamu ya Dik kalau jalan seharian, kamu perempuan di rumah saja kalau sudah datang dari sekolahan.'

\section{Konteks Tuturan}

Seorang kakak marah kepada adik melihat adik baru saja datang.

Tuturan Ikam tu ding mun bajalan jangan barianan, ikam babinian di rumah haja mun sudah datang matan sakulahan 'Kamu, ya Dik kalau jalan seharian, kamu perempuan di rumah saja kalau sudah datang dari sekolahan' dituturkan oleh penutur kepada mitra tutur ketika penutur mengetahui bahwa mitra tutur baru saja datang dari jalan-jalan ke rumah teman. Tuturan itu termasuk tindak tutur bamamai (mengomel) penutur bamamai kepada mitra tutur ketika mengetahui bahwa mitra tutur baru saja datang dari rumah temannya. Berdasarkan skala kesantunan yang dikemukakan oleh Leech dalam Rahardi (2015), yaitu skala ketidaklangsungan dituturkan oleh penutur termasuk tuturan yang tidak santun. Skala indirectness scale itu menunjuk peringkat langsung atau tidak langsungnya maksud sebuah tuturan. Tuturan yang semakin bersifat langsung akan dianggap semakin tidak santun tuturan itu. Sebaliknya, tuturan semakin tidak langsung, akan dianggap semakin santun.

\section{Data 14}

Kanapa garang nyawa ne bahutang tarus padahal bagaji haja saban bulan, imbah diutangi kada sing bayaran unda parlu jua duit.

'Mengapa kamu berutang terus padahal mempunyai gaji saja setiap bulan; setelah diberi utang, tidak pernah dibayar, saya juga perlu uang.'

\section{Konteks tuturan:}

Penutur marah ketika mitra tutur tidak membayar utang.

Tuturan Kanapa garang nyawa ne bahutang tarus padahal bagaji haja saban bulan, imbah diutangi kada sing bayaran unda parlu jua duit 'Mengapa kamu berutang terus padahal mempunyai gaji saja setiap bulan, setelah diberi utang, tidak pernah dibayar, saya juga perlu uang' termasuk tindak tutur bamamai (mengomel). Penutur bamamai 
kepada mitra tutur karena sewaktu penutur menangih utang, mitra tutur tidak mau membayar dengan alasan gaji tidak cukup untuk membayar utang. Berdasarkan skala kesantunan yang dikemukakan oleh Leech dalam Rahardi (2015), yaitu skala jarak sosial (social distance scale), tuturan yang dituturkan oleh penutur termasuk tuturan yang tidak santun. Berdasarkan skala itu ada kecenderungan, semakin dekat jarak peringkat sosial di antara keduanya, semakin kurang santun tuturan tersebut.

\section{PENUTUP}

Berdasarkan analisis data, dapat disimpulkan bahwa dalam tindak tutur bamamai (mengomel) terdapat penerapan skala kesantunan yang dikemukan Leech dalam Rahardi (2015), yaitu (1) penerapan skala kerugian dan keuntungan terjadi ketika tuturan antara penjual dan pembeli; (2) penerapan skala keotoritasan terjadi ketika tuturan antara ibu dan anaknya yang tidak menurut pada waktu dinasihati, dan (3) penerapan skala jarak social terjadi ketika tuturan antara penutur dan mitra tutur yang berjanji akan pergi bersama; penutur mengomel ditinggalkan oleh mitra tutur.

Selain itu, terdapat juga pelanggaran terhadap skala kesantunan yang dikemukan oleh Leech dalam Rahardi (2015), yaitu (1) pelanggaran terhadap skala ketidaklangsungaan terjadi ketika tuturan seorang ibu yang mengomel kepada anaknya dan tuturan lain ketika penutur bamamai (mengomel) karena mitra tutur tidak paham dengan apa yang dikatakan oleh penutur, (2) pelanggaran terhadap skala pilihan terjadi ketika penutur mengajak mitra tutur, muka mitra tutur tetap cemberut, dan (3) pelanggaran terhadap skala jarak social terjadi ketika seorang ibu bamamai (mengomel) kepada anak yang lambat pada waktu disuruh makan. Tuturan lain yang melanggar skala sosial adalah ketika penutur marah kepada mitra tutur karena menyalahkan anak penutur yang nakal.

\section{DAFTAR PUSTAKA}

Chaer, A. (2010). Kesantunan berbahasa. Jakarta: Rineka Cipta.

Hapip, A. D. (2008). Kamus Banjar-Indonesia. Banjarmasin: CV Rahmat Hafiz Al Mubaraq.

Holmes, J. (2001). An Instroduction to Sociolingusitics. New York: Longman Publishing. Jahdiah. (2010). Realisasi Kesantunan Tindak Tutur Menolak Bahasa Banjar. Tesis. Program Pascasarjana Universitas Lambung Mangkurat. Banjarmasin.

Jumanto. (2017). Pragmatik: Dunia Lingusituk Tak Selebar Daun Kelor. Semarang: Morfolingua.

Musdalifah, dkk. (2008). Kamus bahasa Banjar Dialek Hulu-Indonesia. Banjarmasin: 
Balai Bahasa Banjarmasin.

Pranowo. (2012). Berbahasa Santun. Yogjakarta: Pustaka Pelajar.

Putrayasa, I. B. (2015). Pragmatik. Yogyakart: Graha Ilmu.

Rahardi, K. (2005). Pragmatik Kesantunan Imperatif Bahasa Indonesia. Jakarta: Erlangga.

Rahardi, K. (2016). Pragmatik: Fenomena Ketidaksantunan Berbahasa. Yogyakarta: Erlangga.

Sudaryanto. (2015). Metode Dan Teknik Analisis Bahasa: Pengantar Penelitian Wahana Kebudayaan Secara Lingusitik. Yogyakarta: Sanata Dharma University Press.

Tri, S. E. (2013). Pragmatik Suatu Kajian Awal. Surakarta: UNS Press.

Wahyu. (2006). Pedoman Penulisan Karya Ilmiah. Banjarmasin: FKIP Universitas Lambung Mangkurat.

Yayuk, R. (2015). “Etika Berbahasa dalam Masyarakat Banjar”. dalam Jurnal Mlangun. Jurnal Ilmiah Kebahasaan dan Kesastraan, 9 (1), 227-234.

Yayuk, R. (2016). "Wujud Kesantunan Asertif dan Imperatif dalam Bahasa Banjar". Ranah: Jurnal Kajian Bahasa 5 (2). https://doi.org/10.26499/rnh.v5i2.147

Yule, G. (2006). Pragmatik. Banjarmasin: Unlam.

Yusri. (2016). Ilmu Pragmatik dalam Perspektif Kesopanan Berbahasa. Yogyakarta: CV Budi Utama.

Zaini, A. (2009). “Kesantunan Direktif Bahasa Banjar”. Banjarmasin: Tesis Magister Tidak Diterbitkan. In FKIP Program Pascasarjana. Universitas Lambung Mangkurat. Banjarmasin. 